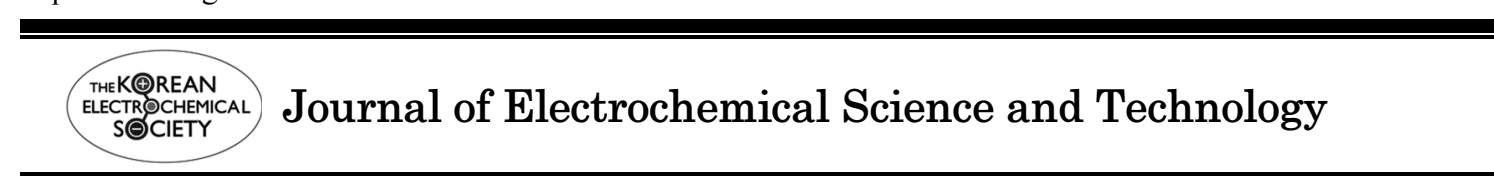

\title{
The Scientific Legacy of Su-Moon Park: a Personal View
}

\author{
Donald A. Tryk \\ Fuel Cell Nanomaterials Center, University of Yamanashi, 6-43 Miyamae-cho, Kofu, Yamanashi 400-0021, Japan
}

\begin{abstract}
:
The late Professor Su-Moon Park was an exemplary scientist, teacher and human being. It was my good luck and privilege to have had the opportunity of working under his guidance as a graduate student. Herein, I describe briefly the development and growth of some of the ideas in his career and how he and they influenced my career.
\end{abstract}

Keywords: Organic electrochemistry, Polycyclic aromatic hydrocarbons, Electrogenerated chemiluminescence

Received December 23, 2013 : Accepted December 30, 2013

\section{Introduction}

In the Fall of 1976, I became a graduate student at the University of New Mexico and there began taking a class in electrochemistry taught by Professor Su-Moon Park, who was a brand-new faculty member, recently having gotten his $\mathrm{PhD}$ under the direction of Professor Allen J. Bard at the University of Texas. It was to become a life-changing experience to be taught by this bright, energetic, young professor. I ended up working in his group, doing research in organic electrochemistry, and becoming one of the first of his students to earn a $\mathrm{Ph} . \mathrm{D}$. Subsequently, he continued to build an impressive career, contributing greatly to several areas in electrochemistry. The ideas he developed were based on his early experiences, and the ideas I have been developing have also been based on my early experiences in his group.

\section{Early Influences}

After graduating from Seoul National University and working in industry for several years, Su-Moon Park decided in 1970 to take a giant step, moving to the USA

*Corresponding author. Tel.: +81-55-254-7137

E-mail address: donald@yamanashi.ac.jp and entering graduate school. As a Master's student in the Department of Chemistry at Texas Tech University, Park came into contact with two of the University's leading lights, Professor Pill-Soon Song and Professor Henry Shine. Song was a great role model, being a major researcher in photobiology as well as being the editor of the Photochemistry and Photobiology. He made many contributions to the understanding of light receptors in biological systems, as well as to the mutagenic effects of photoexcited molecules, ${ }^{1,2}$ Shine was an authority on radicals and electron spin resonance spectroscopy. ${ }^{3}$ Park also met Professor William Herndon of the University of Texas at El Paso, who was a quantum chemist and an authority on conjugated $\pi$ bonded systems and graph theory. ${ }^{4-6}$ From all three men, Park learned the art of identifying a fertile research area and then developing it intensively. From Song, he gained a deep appreciation of photochemistry. From Shine, Park began to appreciate the interesting aspects of radicals, cation, anion and neutral, which were highly important in his $\mathrm{PhD}$ work. From Herndon, he learned to appreciate $\pi$-conjugated systems, which were also important in his PhD work and became even more important in his subsequent development as a young faculty member, specifically on the electrochemistry of both polycyclic aromatic hydrocarbons and conductive polymers. 


\section{Graduate Studies}

Park then joined the group of Professor Allen J. Bard at the University of Texas at Austin in 1972 and began working on one of Bard's well known projects, electrogenerated chemiluminescence (ECL).$^{7-10}$ This was to become an area shared between these two scientists. ECL is an intriguing phenomenon in which an electrochemical reaction produces light: a cation radical is produced at the positive electrode in an electrochemical cell, and an anion radical is produced at the negative electrode, in close proximity to each other, so that they can combine with each other to produce an electronically excited species such as an excited dimer (excimer), if the radicals are produced from the same compound, or an excited complex (exciplex), if the radicals are produced from different compounds. ${ }^{11}$ Typically, relatively large polycyclic aromatic compounds are used in order to stabilize the charges, by allowing the charge to be highly delocalized.

In Austin, the art of identifying broad research ideas in need of development was reinforced. Bard continued a long string of numbered ECL papers and also initiated another long string of numbered papers on semiconductor electrochemistry. At the time that Park was at UTAustin, the Bard group was without a doubt one of the most active in the field of electrochemistry. Professor Larry Faulkner was also at UT-Austin, and he and Bard began collaborating on one of the best-known books on electrochemistry, Electrochemical Methods. ${ }^{12}$ Many members of the Bard group went on to high-level positions in industry and academia. Park was able to graduate in only three years with his $\mathrm{PhD}$, demonstrating his work ethic and focus.

\section{University of New Mexico}

In 1975, Park joined the faculty of the Department of Chemistry at the University of New Mexico in Albuquerque, New Mexico. Even though the Department was not at the level of the University of Texas, for example, Park decided that it was a place where he could build his career. The Department had a number of excellent faculty members, including several of his own generation, and it had close ties to Sandia National Laboratory, also in Albuquerque, and Los Alamos National Laboratory. The Department Chair was Professor Guido Daub, a prolific synthetic organic chemist. Park joined the other members of the analytical chemistry division, including Professor Thomas Niemczyk, an expert in atomic absorption spectroscopy, and Professor Thomas Jones, an expert in separations. In 1973, I was working as an analytical chemist with the State of New Mexico's Department of Health and decided that I should take advantage of the opportunity to take part-time classes at the University of New Mexico, so I began to take classes in the analytical division. Finally, in 1976, I decided to enter graduate school full-time. It was then that I first met Professor Park, as a student in his course in electrochemistry.

Through the enthusiasm of Professor Park, I quickly became interested in electrochemistry. At that time, it was a very mysterious subject for me, having only been exposed to potentiometric methods with ion-selective electrodes as an analytical chemist. It became clear that the subject was much larger, encompassing all sorts of interesting phenomena and applications. I checked out every book in the library that I could find on the subject and found several by Professor John Bockris that also fueled my enthusiasm. ${ }^{13,14}$ Bockris was a very interesting writer, with a unique viewpoint, which involved heavy criticism of the analytical bent of most electrochemists at that time. In his classes, Park also talked about many non-analytical aspects of electrochemistry, having come from the Bard group, in which every possible aspect was represented.

At that time, I was very much excited by the prospect of photoelectrochemical water splitting, which had been published for the first time by Fujishima and Honda in 1972, a paper that engendered intense interest around the world. ${ }^{15}$ Park was starting a project on this topic, and I was keen to work on it, but another student, James Wilson, selected it first. ${ }^{16,17}$ Little did I know at that time that I would have a chance to work with Professor Fujishima in Japan, although on other topics.

My second choice was the electrochemistry of polycyclic aromatic hydrocarbons (PAH), many of which had been shown to be both mutagens and carcinogens. This was an area that Park had become interested in at Texas Tech. Luckily, Professor Daub at UNM had synthesized a number of different monomethyl and dimethyl benzo[a]pyrenes $(\mathrm{B}[\mathrm{a}] \mathrm{P})$, which could be examined electrochemically (see Fig. 1A for the B[a]P structure). One undergraduate student, Jon Michnovicz, and I started to work on this topic, he taking the dimethyl $\mathrm{B}[\mathrm{a}] \mathrm{P}$ compounds ${ }^{18}$ and I taking the monomethyl compounds. ${ }^{19}$ I preferred the latter, because we had the possibility of examining all twelve of the possible isomers, 


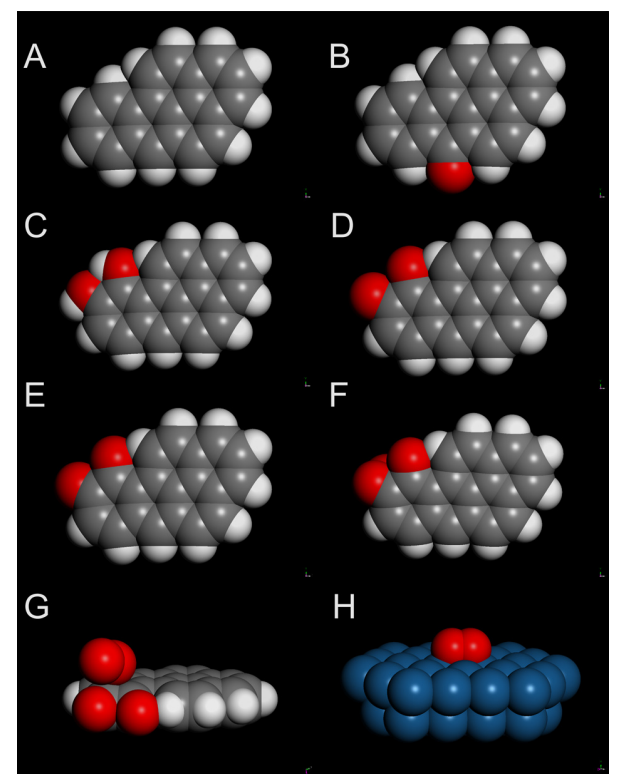

Fig. 1. Space-filling representations of optimized structures for (A) benzo[a]pyrene (B[a]P); (B) B[a]P-6-oxo radical; (C) B[a]P-9,10-diol; (D) B[a]P-9,10-dione; (E) B[a]P-9,10-dione anion radical; (F) B[a]P-9,10-dione anion radical adduct with $\mathrm{O}_{2}$, front view; $(\mathrm{G}) \mathrm{B}[\mathrm{a}] \mathrm{P}-9,10$-dione anion radical adduct with $\mathrm{O}_{2}$, side view; $(\mathrm{H}) \mathrm{Pt}(111)$ 40-atom cluster with $\mathrm{O}_{2}$ adsorbed in a bridging configuration. The optimizations were carried out with the Accelrys $\mathrm{DMol}^{3}$ density functional theory package $(54,55)$ using the dspp pseudopotential $(56)$.

checking their electrochemical properties and comparing those with their mutagenic properties. It was also possible to carry out extended Hückel molecular orbital calculations on such compounds, as well as their oxidation products. It was at this point that I became interested in theoretical calculations, which seemed even more mysterious than electrochemistry.

When I started this work, there were several different hypotheses that were being tested around the world regarding the reasons for the mutagenicity of $\mathrm{B}[\mathrm{a}] \mathrm{P}$, one of these being the fact that it was able to form a relatively stable oxo radical (Fig. 1B), due to the effective conjugation with the benzo ring system. Even though it is stabler than other radicals, it was thought to be sufficiently reactive to covalently bind to DNA bases. ${ }^{20,21}$ Therefore, my research plan involved testing this hypothesis electrochemically, by determining the stability of the respective oxo radicals of this set of compounds. ${ }^{19}$ As it turned out, there was not a statistically significant relationship between the radical stability and the carcinogenicity data that we were able to find. This was not surprising in retrospect, because a group at the US National Institutes of Health was coming up with the real reason for the high activity of $\mathrm{B}[\mathrm{a}] \mathrm{P}$ compared to the other $\mathrm{BP}$ isomer, $\mathrm{B}[\mathrm{e}] \mathrm{P}$, in which the benzo ring attached to pyrene was in a different position. These workers found that for $\mathrm{B}[\mathrm{a}] \mathrm{P}$ and other similar compounds, there is a "bay" region (due to its bay-like shape) that is easily attacked by cytochrome P-450 to produce a highly mutagenic product, a diol epoxide. ${ }^{22,23}$ The latter was found to be a precursor for a radical that was able to covalently bind to DNA bases.

Even though this was almost certainly the major pathway for the mutagenesis, we were able to show that, if one oxidized $\mathrm{B}[\mathrm{a}] \mathrm{P}$ electrochemically in the presence of water and DNA, the oxidation products, which could have included the oxo radical, were able to bind covalently to DNA. ${ }^{24}$

Also, as it turns out, another well-known electrochemist, Professor Ralph Adams of the University of Kansas, who had also written an influential electrochemistry book, ${ }^{25}$ was studying the electrochemical oxidation of $\mathrm{B}[\mathrm{a}] \mathrm{P}$ and found that the oxidation products included several diones or quinones (see, e.g., Fig. 1D), which can easily be converted electrochemically or chemically to the corresponding anion radicals (semiquinones) (Fig. 1E). ${ }^{26}$ Other groups had found that the chemical or electrochemical reduction of the quinones of PAHs and similar aromatic systems can produce semiquinones, which can in turn reduce dioxygen to the superoxide anion radical $\mathrm{O}_{2}{ }^{-}$, if their standard electrode potential is negative enough (see Figs. 1F, 1G) (27). These diones then have the possibility of being cytotoxic.

Parenthetically, the interaction of $\mathrm{O}_{2}$ with non-metallic systems such as this is still a matter of some controversy, which is beyond the scope of the present paper. Briefly, we find a significant difference in $\mathrm{O}_{2}$ adsorption behavior comparing a semiquinone such as that shown in Figs. $1 \mathrm{~F}$ and $1 \mathrm{G}$ with that for a metal surface such as $\mathrm{Pt}(111)$ (Fig. 1H). We intend to report those results in a separate publication.

Certainly, we were a bit disappointed that we did not find the key to the mutagenicity of PAHs, but we felt that it was useful to have tested our hypothesis. There were other benefits for me, such as a long-term interest in carbonaceous materials and also a long-term interest in dioxygen reduction, both of which have continued to the present. Later, when I went to work for Professor Yeager at Case Western Reserve University (CWRU), I 
found that one of his great interests was dioxygen reduction on non-metallic electrodes such as graphite. ${ }^{28-}$ ${ }^{30}$ We then worked on elucidating the surface functional groups on carbon and graphite surfaces that might be catalytic sites, concluding that these were quinonelike. ${ }^{31}$ Also, the same reaction pathways that Jeftic and Adams had identified for $\mathrm{B}[\mathrm{a}] \mathrm{P}^{26}$ are generically the same as those occurring during the oxidative degradation of carbon black support materials in polymer electrolyte fuel cells. ${ }^{32}$

Another one of Park's early students was an undergraduate, Mark Paffett, who later became a graduate student at Caltech with Professor Fred Anson, publishing a large number of interesting papers. There, he met a graduate student from Korea named Chi-Woo Lee, the current President of the Korean Electrochemical Society. At that time, Lee and Park did not know each other but later became close associates, especially when Park returned to Korea. Paffett later worked at Los Alamos National Laboratory and carried out some interesting work on platinum-chromium alloy catalysts for dioxygen reduction in acid solution as a model system for a proton-conducting ionomer.

In that work, he and the other authors claimed that the enhancement in the electrocatalysis was due simply to the increased roughness of the surface that developed when the chromium was leached out in the acidic environment. ${ }^{33}$ Even at present, in our work at the Fuel Cell Nanomaterials Center, we cite this paper, because it was the first to state this surface area model for enhanced alloy catalysis. However, even though this model might be valid for platinum-chromium, we believe that it is not valid for our catalyst of choice, platinum-cobalt. For the latter, our Center's Director, Professor Masahiro Watanabe, proposed in 1994 that the enhanced catalysis was due to an electronic effect of the alloy acting through an extremely thin, pure platinum "skin" layer, even after correction for any changes in surface area. ${ }^{34}$

In fact, Professor Watanabe and his group have been working on the detailed explanation of this effect at present, using a combination of several powerful experimental techniques, including X-ray photoelectron spectroscopy combined with electrochemistry (EC-XPS) ${ }^{35-}$ 38 and electrochemical quartz crystal microbalance (EQCM) ${ }^{39,40}$ as well as density functional theory (DFT) calculations. Many other groups have also been working on this problem, and there has been a kind of consensus that first-row transition metals such as iron, cobalt and nickel, when alloyed with platinum, weaken the adsorption of the dissociation products of dioxygen, $\mathrm{O}$ and $\mathrm{OH}$, which could otherwise tie up adsorption sites at which $\mathrm{O}_{2}$ could adsorb. ${ }^{41}$ However, we are finding evidence to the contrary. We, like Professor Park, believe in doing electrochemistry in our own way.

The largest research area that Park claimed as his own was the electrochemistry of conductive polymers. When I was at UNM, another PhD student, David Stilwell, was already starting to work on the first papers in this long numbered series. These papers are among the most highly cited of Park's impressive list of publications. $^{42-47}$ The general theme of imbuing organic polymers with interesting, useful properties such as electronic conductivity was then just at the very beginning, but it continues even today. Polyaniline, for example, has turned out to be an exceedingly versatile material, finding applications in electroanalysis, batteries and fuel cells.

One of the other areas that Park pioneered was the electrochemistry of coal slurries. Another member of our early group, Patrick Dhooge, was the PhD student working on this topic. One of the motivations was to see if coal could be utilized directly as a fuel in an electrochemical cell, without much preprocessing. ${ }^{48-50}$ This line of research was definitely something novel, and one could just proceed without worrying whether someone else was doing the same thing, but there were also very few guidelines. However, this did not deter Professor Park. This was a good example of his fearless approach. The idea of using solid carbonaceous fuels directly in fuel cells continues even today.

Professor Park continued to be a strong contributor to the Department of Chemistry. One of his contemporaries was Professor Robert T. Paine, an inorganic chemist and pillar of the Inorganic Division. Paine writes, "SuMoon Park and I were close friends and colleagues, and it was with great sadness that I learned of his recent passing. We shared many of the same professional experiences during the start of our independent scientific careers in the Chemistry Department at the University of New Mexico. We both began, one year apart, as Assistant Professors in a department where teaching loads were high and research progress was accomplished against many internal and external hurdles with minimal financial backing. During the twenty years that we were colleagues, we witnessed many changes in the local education culture, and we and others molded a dramatically different organization within the Chemistry Department. In this period, Su-Moon was a steady, 
dependable leader. He was a creative and demanding classroom instructor in both the undergraduate and graduate programs. He was also a wonderful mentor to his own graduate students and other students in the Analytical program. The impact of his research program initiated at UNM was extensive at the time and his contributions continue to be trend setting today. SuMoon's leadership and grace has been greatly missed since his return home to Pohang University."

\section{Pohang University of Science and Tech- nology}

While at the Electrochemical Society Annual Meeting in St. Louis in 1979 to present my graduate research, to which we had journeyed in Professor Park's automobile, I met Professor Ernest B. Yeager of Case Western Reserve University. I ended up working at CWRU with him for many years. Then, in 1995, at the suggestion of Professor Daniel Scherson, I applied to work with Professor Akira Fujishima, of photo-assisted water splitting fame, at the University of Tokyo. Soon after joining Fujishima, Professor Park very kindly invited me to visit him in his laboratory at the newly established Pohang University of Science and Technology (Postech), which he had just recently joined. He was so kind that he arranged for me to take a grand lecture tour of Korea, including stops in Pusan to visit Professor Yoon-Bo Shim of Pusan National University, with whom he was collaborating, Dr. Gwanghoon Kwag of Kumho Petrochemical in Daejeon, who had been at CWRU working with the well-known inorganic chemist, Professor Malcolm Kenney, and Dr. Chong-Hong Pyun of the Korean Institute of Science and Technology in Seoul, who had gotten his PhD at UNM shortly after me and was an expert on inorganic phosphors and digital instrumentation.

Later, Professor Park visited the Fujishima Laboratory in Tokyo, and these two men started a new collaboration on diamond electrochemistry. Fujishima had a large project on this topic, and I was one of the members of the diamond group. In fact, Professor Park and Professor Fujishima published three papers together, ${ }^{51-53}$ two of which I was a coauthor. As you can see, one can work together over many decades!

Not too long ago, Professor Park and Professor Watanabe had a chance to meet at a conference to commemorate the retirement of Professor Hasuck Kim from Seoul National University. This also became a chance to renew my contact with Park, and he and I corresponded about another possible visit to Korea, which he was planning for me. Early this year, I was greatly saddened, as were many people, to hear of his passing. We miss him very much. Let us strive to keep his fearless, independent investigative spirit alive.

\section{Acknowledgements}

The author greatly appreciates the work of the organizers and participants of the Su-Moon Park Memorial Symposium held at the Autumn Meeting of the Korean Electrochemical Society in November 2013 in Daejeon, Korea.

\section{References}

1. P.S. Song and K.J. Tapley, Photochemistry and Photobiology, 29, 1177 (1979).

2. W.M. Horspool and P.S. Song, CRC Handbook of Organic Photochemistry and Photobiology, p. 1664, CRC Press (1995).

3. C.V. Ristagno and H.J. Shine, Journal of Organic Chemistry, 36, 4050 (1971).

4. W.C. Herndon and M.L. Ellzey, Journal of the American Chemical Society, 96, 6631 (1974).

5. W.C. Herndon, Journal of the American Chemical Society, 95, 2404 (1973).

6. W.C. Herndon, Tetrahedron, 29, 3 (1973).

7. S.M. Park and A.J. Bard, Journal of Electroanalytical Chemistry, 77, 137 (1977).

8. S.M. Park and A.J. Bard, Chemical Physics Letters, 38, 257 (1976).

9. S.M. Park and A.J. Bard, Journal of the American Chemical Society, 97, 2978 (1975).

10. R.E. Hemingway, S.M. Park and A.J. Bard, Journal of the American Chemical Society, 97, 200 (1975).

11. S.M. Park and D. Tryk, Reviews of Chemical Intermediates, 4, 43 (1981).

12. A.J. Bard and L.R. Faulkner, Electrochemical Methods: Fundamentals and Applications, p. 856, Wiley, New York (2000).

13. J.O'M. Bockris and Z. Nagy, Electrochemistry for Ecologists, Springer (1974).

14. J.O'M. Bockris, A.K.N., Modern Electrochemistry: An Introduction to an Interdisciplinary Area, Plenum Publishing Corporation, New York (1977).

15. A. Fujishima and K. Honda, Nature, 238, 37 (1972).

16. J.R. Wilson and S.M. Park, Journal of the Electrochemical Society, 128, 2369 (1981).

17. J.R. Wilson and S.M. Park, Journal of the Electrochemical Society, 128, C114 (1981).

18. S.M. Park, J.J. Michnovicz and G.H. Daub, Analytical Biochemistry, 90, 374 (1978). 
19. D.A. Tryk, S.M. Park and G.H. Daub, Journal of The Electrochemical Society, 130, 597 (1983).

20. E. Rogan, R. Roth, P. Katomski, J. Benderson and E. Cavalieri, Chemico-Biological Interactions, 22, 35 (1978).

21. E. Cavalieri, R. Roth, C. Grandjean, J. Althoff, K. Patil, S. Liakus and S. Marsh, Chemico-Biological Interactions, 22, 53 (1978).

22. A.W. Wood, R.L. Chang, W. Levin, H. Yagi, D.R. Thakker, D.M. Jerina and A.H. Conney, Biochemical and Biophysical Research Communications, 77, 1389 (1977).

23. A.W. Wood, R.L. Chang, W. Levin, R.E. Lehr, M. Schaeferridder, J.M. Karle, D.M. Jerina and A.H. Conney, Proceedings of the National Academy of Sciences of the United States of America, 74, 2746 (1977).

24. D.A. Tryk and S.M. Park, J. Am. Chem. Soc., 103, 2123 (1981).

25. R.N. Adams, Electrochemistry at Solid Electrodes, p. 416, CRC Press (1969).

26. L. Jeftic and R.N. Adams, Journal of the American Chemical Society, 92, 1332 (1970)

27. M. Bobrowski, A. Liwo and K. Hirao, The Journal of Physical Chemistry B, 111, 3543 (2007).

28. E. Yeager, P. Krouse and K.V. Rao, Electrochimica Acta, 9, 1057 (1964).

29. I. Morcos and E. Yeager, Electrochimica Acta, 15, 953 (1970).

30. E. Yeager, J. Electrochem. Soc., 128, 160C (1981).

31. M.S. Hossain, D. Tryk and E. Yeager, Electrochim. Acta, 34, 1733 (1989).

32. Y.C. Park, K. Kakinuma, M. Uchida, D.A. Tryk, T. Kamino, H. Uchida and M. Watanabe, Electrochimica Acta, 91, 195 (2013).

33. M. T. Paffett, J. G. Beery and S. Gottesfeld, Journal of The Electrochemical Society, 135, 1431 (1988).

34. M. Watanabe, K. Tsurumi, T. Mizukami, T. Nakamura and P. Stonehart, Journal of The Electrochemical Society, 141, 2659 (1994).

35. M. Wakisaka, H. Suzuki, S. Mitsui, H. Uchida and M. Watanabe, J. Phys. Chem. C, 112, 2750 (2008).

36. M. Wakisaka, H. Suzuki, S. Mitsui, H. Uchida and M. Watanabe, Langmuir, 25, 1897 (2009).
37. M. Wakisaka, M. Watanabe and H. Uchida, in Fuel Cell Science: Theory, Fundamentals, and Biocatalysis, A. Wieckowski and J.K. Nørskov Editors, p. 147, John Wiley \& Sons, Inc., Hoboken, NJ, USA (2010).

38. M. Watanabe, D.A. Tryk, M. Wakisaka, H. Yano and H. Uchida, Electrochimica Acta, 84, 187 (2012).

39. J. Omura, H. Yano, M. Watanabe and H. Uchida, Langmuir, 27, 6464 (2011).

40. J. Omura, H. Yano, D.A. Tryk, M. Watanabe and H. Uchida, Langmuir, in press (2013).

41. Y. Xu, A.V. Ruban and M. Mavrikakis, J. Am. Chem. Soc., 126, 4717 (2004).

42. Y.B. Shim, D.E. Stilwell and S.M. Park, Electroanalysis, 3, 31 (1991).

43. D.E. Stilwell and S.M. Park, Journal of the Electrochemical Society, 136, 688 (1989).

44. D.E. Stilwell and S. M. Park, Journal of the Electrochemical Society, 136, 427 (1989).

45. D.E. Stilwell and S.M. Park, Journal of the Electrochemical Society, 135, 2497 (1988).

46. D.E. Stilwell and S.M. Park, Journal of the Electrochemical Society, 135, 2491 (1988).

47. D.E. Stilwell and S.M. Park, Journal of the Electrochemical Society, 135, 2254 (1988).

48. P.M. Dhooge and S.M. Park, Journal of the Electrochemical Society, 130, 1539 (1983).

49. P.M. Dhooge and S.M. Park, Journal of the Electrochemical Society, 130, 1029 (1983).

50. P.M. Dhooge, D.E. Stilwell and S.M. Park, Journal of the Electrochemical Society, 129, 1719 (1982).

51. N. Spataru, C. Terashima, K. Tokuhiro, I. Sutanto, D.A. Tryk, S.M. Park and A. Fujishima, Journal of the Electrochemical Society, 150, E337 (2003).

52. J. Lee, D.A. Tryk, A. Fujishima and S.M. Park, Chemical Communications, 486 (2002).

53. J. Lee, Y. Einaga, A. Fujishima and S.M. Park, Journal of the Electrochemical Society, 151, E265.

54. B. Delley, The Journal of Chemical Physics, 92, 508 (1990).

55. B. Delley, The Journal of Chemical Physics, 113, 7756 (2000).

56. B. Delley, Physical Review B, 66, 155125 (2002). 